\title{
Anthropometric and Somatotyping Study among the Female Kho-Kho Players of Pondicherry: A Comparative Analysis
}

\section{Ajeet Jaiswal*}

Department of Anthropology, Pondicherry University, Puducherry, India

\begin{abstract}
Performance in different games is supposed to be related to better physical fitness. The purpose of this study was to find out anthropometric measurements, body composition and somatotyping differences among female KhoKho players and controls. 99 young female subjects (Kho-Kho players: $\mathrm{N}=49$ and controls: $\mathrm{N}=49$ ) of age group 18-24 years were randomly selected from the participant of South zone interuniversity Kho-Kho tournament for women, 2011-12, organized by Physical education and sports department, Pondicherry University, India. All the participants were assessed for height, weight, breadths, girths and skinfold thickness. The independent samples t-test revealed that Kho-Kho players had significantly higher height $(p<0.05)$, as compared to controls. The Kho-Kho players were also found to have significantly greater lean body mass $(p<0.01)$ and ectomorph component $(p<0.05)$ as compared to controls. Controls had significantly greater percent body fat and total body fat $(p<0.05)$ as compared to Kho-Kho players. The Kho-Kho players of this study were found to have higher percentage body fat with lower body height and body weight than their international counterparts. Further investigations are needed on above studied variables along with fitness and physiological variables to assess relationship among them and with performance in Kho-Kho. The findings of the present study might be useful in future investigation on player selection, talent identification in the game of Kho-Kho and its training programmed development.
\end{abstract}

Keywords: Kho-Kho players; Anthropometry; Somatotyping; Sports; Body fat

\section{Introduction}

Kho-Kho ranks as one of the most popular traditional sports in India. Kho Kho is an extremely complicated and tactical sport. Kho Kho is a tag sport played by teams of twelve players who try to avoid being touched by members of the opposing team; only 9 players of the team enter the field. It is one of the two most popular traditional tag games of South Asia, the other being Kabbadi. Apart from South Asia (mainly Bangladesh, India and Pakistan), it is also played in South Africa [1].

The origin of Kho-Kho is difficult to trace, but many historians believe, that it is a modified form of 'Run Chase', which in its simplest form involves chasing and touching a person. With its origins in Maharashtra, Kho-Kho in ancient times, was played on 'raths' or chariots, and was known as Rathera. Dodging, feinting and bursts of controlled speed make this game quite thrilling. To catch by pursuit to chase, rather than just run - is the capstone of Kho-Kho. The game develops qualities such as obedience, discipline, sportsmanship, and loyalty between team members.

Morphological characteristics are most important factor because to a great extent these are genetically determined [2]. The anthropometric measurements are used to determine the morphological status, that is, body constitution and body structure of an athlete. It is well known fact that a general relationship exists between morphology and performance.

Several studies on various body characteristics of different sports activities have been carried out by many researchers and they concluded that strong relationship exist between structure and performance [3-8]. Physical performance declines when body weight and percentage of body fat is at extreme level [9], but depending on the sport, a higher or lower body fat level may be beneficial. Because of this, body composition trends in different sports can help identify potential participants. The top athletes in a particular sport or event show similarities in body dimension and body constitution [5].
Various researchers also suggested that different body size, shape and proportions are beneficial in different physical activities [10,11]. Thus the model body type for a specific sport or event is most easily determined by studying the top level athletes. The knowledge of these characteristics assists the coaches in planning better training programs while preparing their athletes for competition. The present study, therefore, has been conducted on the participant of South zone interuniversity Kho-Kho tournament for women, 2011-12, organized by Physical education and sports department, Pondicherry University, India and controls subjects to evaluate their somatic traits and body composition.

\section{Material and Methods}

The present study was conducted on 48 young female subjects (Kho-Kho players: $\mathrm{N}=48$ and controls: $\mathrm{N}=49$ ) of $18-24$ years age. The subjects were randomly selected from the participant of South zone interuniversity Kho-Kho tournament for women (Table 1), 2011-12, organized by Physical education and sports department, Pondicherry University, India. A written as well as oral consent was obtained from the subjects. Anthropometric measurements like height, weight, Skinfold thickness, Girths and Widths of the subjects were measured with anthropometric rod, portable weighing machine, skinfold caliper, steel tape and sliding caliper respectively using standard procedure of Weiner and Lourie.

${ }^{*}$ Corresponding author: Ajeet Jaiswal, Assistant Professor, Department of Anthropology, Pondicherry University, Puducherry, India, Tel: +919791201427; E-mail:rpgajeet@gmail.com

Received September 29, 2014; Accepted October 08, 2014; Published October 15,2014

Citation: Jaiswal A (2014) Anthropometric and Somatotyping Study among the Female Kho-Kho Players of Pondicherry: A Comparative Analysis. J Glob Econ 2 122. doi: $10.4172 / 2375-4389.1000122$

Copyright: ( 2014 Jaiswal A. This is an open-access article distributed under the terms of the Creative Commons Attribution License, which permits unrestricted use, distribution, and reproduction in any medium, provided the original author and source are credited. 


\begin{tabular}{|c|c|c|c|}
\hline \multirow{3}{*}{ Somatotype } & $\begin{array}{l}\text { Endomorphy }=-0.7182+0.1451(X)-0.00068\left(X^{2}\right)+ \\
0.0000014\left(X^{3}\right)\end{array}$ & $\begin{array}{l}\text { Where } X=\text { (sum of triceps, subscapular and supraspinale } \\
\text { skinfolds) multiplied by }(170.18 / \text { height in } \mathrm{cm}) \text {. } \\
\text { This is called height-corrected endomorphy and is the } \\
\text { preferred method for calculating endomorphy }\end{array}$ & \multirow{3}{*}{ Heath \& Carter, (1990) } \\
\hline & $\begin{array}{l}\text { Mesomorphy }=(0.858 \times \text { humerus width })+(0.601 \times \\
\text { femur width })+(0.188 \times \text { corrected arm girth })+(0.161 \\
\times \text { corrected calf girth })-(\text { body height } \times 0.131)+4.5\end{array}$ & $\begin{array}{l}\text { (Where corrected arm girth = arm girth-biceps skinfold, } \\
\text { corrected calf girth = calf girth-calf skinfold). }\end{array}$ & \\
\hline & Ectomorphy $=(H W R \times 0.732)-28.58$ & $($ Where HWR $=($ body height in $\mathrm{cm}) /($ weight in $\mathrm{kg}) 1 / 3)$. & \\
\hline Body fat (\%) & Body fat (\%) as estimated from the sum of skinfolds & Calculated using equations of Siri; Durnin and Womersley. & $\begin{array}{l}\text { Siri (1956); Durnin and } \\
\text { Womersley (1974). }\end{array}$ \\
\hline \multirow[t]{2}{*}{ Regression equations } & $\begin{array}{l}\text { For the prediction of body density from the log of the } \\
\text { sum of skinfold thickness at four sites in } \mathrm{mm} \\
\text { For } 17 \text { to } 19 \text { years age group: Body Density }(\mathrm{gm} / \mathrm{cc}) \\
=1.1620-0.0630(\mathrm{X})\end{array}$ & \multirow[t]{2}{*}{ Where $\mathrm{X}=\log$ (biceps+triceps +subcapular +suprailliac). } & \multirow[t]{2}{*}{$\begin{array}{l}\text { Durnin and Womersley, } \\
1974 .\end{array}$} \\
\hline & $\begin{array}{l}\text { For } 20 \text { to } 29 \text { years age group: Body Density }(\mathrm{gm} / \mathrm{cc}) \\
=1.1631-0.0632(\mathrm{X})\end{array}$ & & \\
\hline$\%$ body fat & \multicolumn{2}{|l|}{$(4.95 /$ body density- 4.5$) \times 100$} & Siri, 1956 \\
\hline Total body fat (kg) & \multicolumn{2}{|l|}{$(\%$ body fat $/ 100) \times$ body mass $(\mathrm{kg})$} & \\
\hline Lean body mass $(\mathrm{kg})$ & \multicolumn{2}{|l|}{ body mass $(\mathrm{kg})$ - total body fat $(\mathrm{kg})$} & \\
\hline $\mathrm{BMI}\left(\mathrm{Kg} / \mathrm{m}^{2}\right)$ & \multicolumn{2}{|l|}{ (body mass in Kg) / (Stature in meters) ${ }^{2}$} & Meltzer et al., 1988. \\
\hline Statistical analysis & \multicolumn{3}{|c|}{$\begin{array}{l}\text { Values are presented as mean values and SD. Independent samples t tests were used to test if population means estimated by two } \\
\text { independent samples differed significantly. Data was analyzed using SPSS version } 16.0 \text {. }\end{array}$} \\
\hline
\end{tabular}

Table 1: Anthropometric Measurements.

\section{Results}

The Table 2 explains mean and standard deviation of somatic traits between kho-kho players and control group. The mean value of height and weight of kho-kho players were more than control subjects. In case of body weight difference between kho-kho players and control group are found to be non-significant. Kho-Kho players significantly possess greater stature $(\mathrm{p}<0.01)$ than controls. The result revealed that kho-kho players were found to possess significantly low endomorphic $(\mathrm{p}<0.01)$ rating but high rating of mesomorphic $(\mathrm{p}<0.01)$ and ectomorphic $(\mathrm{p}<0.01)$ components.

It is evident from Table 3 that the mean value of Lean body mass, $\%$ Body fat and Body mass index (BMI) of kho-kho players were less than that of control subjects but the mean value was more in case of Total body fat. Kho-kho players have significantly greater values in percentage of lean body mass than the control group. The lean body mass contribute relatively more to body weight than body fat in khokho players. Their training has resulted in muscular development in the kho-kho which is supported by the fact that sufficiently the kho-kho players have significantly lesser \% body fat $(\mathrm{p}<0.01)$ and BMI $(\mathrm{p}<0.01)$ than the controls.

\section{Discussion}

Performance in different games is supposed to be related to better physical fitness. More stress is being laid on conditioning \& practicing of skills and the use of other valuable devices to achieve better physical fitness by players. In the present study the somatic traits and body composition of the kho-kho players and controls have been evaluated and compared with each other. As the level of performance increases the players attains high degree of physical fitness. Harrare [12] supported this view that the successful participation in any game is directly related to physical fitness. Helga reported that physical fitness improves in those who take regular physical exercises. Regular participation in games significantly contributes to higher level of performance and greater degree of physical fitness amongst the players. Durnin and Womerseley [13] found a low heart rate among champion gymnasts. Low heart rate is the outcome of a good endurance. This study indicates the existence of differences among the kho-kho players and controls.
The overall results show that kho-kho players were taller as compared to the controls. Dhayanithi and Ravikumar [14] also observed that kho-kho players, in each age group are significantly taller than controls with tendency to be more toward ectomorphy.

In kho-kho, teams compete by manipulating skills of spiking and blocking high above the head. Therefore, the presence of tall players is an indispensable factor in the success of a kho-kho team. The kho-kho players in the present study have greater height and percentage of lean body mass than the controls. It is important to highlight that there were no significant differences in body weight between kho-kho players and controls. The kho-kho players also reported to have greater values in lean body mass than the control group.

According to Parizkova [15], LBM compared to total BW is closely related to physiological parameters such as oxygen consumption, cardiac output, vital capacity, etc. According to the study of Barbara [16] kho-kho players show significantly higher LBM values than the non-sporting population. This parameter, including all body tissues except for fat deposits, is considered a major precondition for a good performance in kho-kho.

The kho-kho players in the present study have greater height and percentage of lean body mass than the kho-kho from South India studied by Barbara [16] whereas they are shorter and lighter than their international. The somatotyping scores of kho-kho players in the present study are 2.4- 4.2-3.6 and they are reported as mesomorphectomorph. These results are not in agreement with those of who reported kho-kho players as balanced mesomorphs. On the other hand, the somatic traits scores of kho-kho players in the present study are in conformity with south Asian kho-kho players showed the mesomorphectomorph somatotype with a somatotype score of 2.4-3.5-3.7.

The observations in the present investigation reflected higher fatness among non-sportspersons than sportspersons, In addition, according to body mass index (BMI) results strongly suggest that the controls had greater amount of body fat mass compared to kho-kho players. Based on the results of the present study, we highlight somatic traits and body composition characteristics of kho-kho players as compare to controls. In kho-kho game, anthropometric characteristics, somatic traits, body composition together with physiological, technical, and psychological 
Citation: Jaiswal A (2014) Anthropometric and Somatotyping Study among the Female Kho-Kho Players of Pondicherry: A Comparative Analysis. J Glob Econ 2: 122. doi:10.4172/2375-4389.1000122

Page 3 of 3

\begin{tabular}{|c|c|c|c|c|c|}
\hline \multirow{3}{*}{ Variables } & \multirow{2}{*}{\multicolumn{2}{|c|}{$\begin{array}{c}\text { Kho-Kho } \\
\text { players }(\mathrm{N}=48)\end{array}$}} & \multirow{2}{*}{\multicolumn{2}{|c|}{$\begin{array}{c}\text { Controls } \\
(\mathrm{N}=49)\end{array}$}} & \multirow{3}{*}{ t-value } \\
\hline & & & & & \\
\hline & Mean & SD & Mean & SD & \\
\hline Height $(\mathrm{cm})$ & 162.51 & 8.46 & 152.26 & 5.51 & $5.82^{* *}$ \\
\hline Body weight $(\mathrm{kg})$ & 61.48 & 4.33 & 55.44 & 5.27 & 0.45 \\
\hline Endomorphy & 2.44 & 0.81 & 3.64 & 1.02 & $4.30^{* *}$ \\
\hline Mesomorphy & 4.26 & 1.11 & 3.23 & 0.96 & $3.35^{\star *}$ \\
\hline Ectomorphy & 3.67 & 1.36 & 1.96 & 0.92 & $4.97^{\star *}$ \\
\hline
\end{tabular}

Table 2: Mean values and standard deviations of Somatic Traits of kho-kho Players and Controls.

\begin{tabular}{|c|c|c|c|c|c|}
\hline \multirow{2}{*}{ Variables } & \multicolumn{2}{|c|}{ Kho-Kho } & \multicolumn{2}{c|}{ Controls } & \multirow{2}{*}{ t-value } \\
\cline { 2 - 5 } & players (N=48) & \multicolumn{2}{|c|}{$\mathbf{( N = 4 9 )}$} & \multirow{2}{*}{ t-van } \\
\cline { 2 - 6 } & Mean & SD & Mean & SD & \\
\hline Total body fat $(\mathrm{kg})$ & 7.04 & 2.64 & 9.86 & 2.46 & $2.84^{\star *}$ \\
\hline Lean body mass $(\mathrm{kg})$ & 60.65 & 4.94 & 59.46 & 5.56 & $2.42^{*}$ \\
\hline \% Body fat & 10.62 & 2.24 & 12.44 & 2.56 & $3.48^{\star *}$ \\
\hline Body mass index (BMI) & 22.28 & 2.12 & 24.10 & 2.04 & $2.86^{\star *}$ \\
\hline
\end{tabular}

Table 3: The Mean Value of Lean Body Mass, \% Body Fat and Body Mass Index (BMI) of kho-kho Players.

variables account for performance or selection of athletes.

\section{Conclusion}

There were significant differences in somatic traits and body composition between the kho-kho players and controls. The kho-kho players were significantly taller and had less amount of subcutaneous tissue with more ectomorphic component than the controls. The khokho players also had higher lean body mass than the controls. The $\%$ body fat and total body fat were also lesser in kho-kho players. More data would be helpful on the above studied variables along with fitness and physiological variables to assess relationship among them and with performance in kho-kho.

\section{Acknowledgements}

Author is thankful to female kho-kho players and female students of the University Cooperation and full cooperative support. I also wish to record my appreciation of the help received from the Dr Jyothi, Director (i/c) Physical Education and Sports. I am especially grateful for the assistance and encouragement of my supervisor Prof. A.K. Kapoor and co-supervisor Prof. Satwanti Kapoor for their help during research. The author is also thankful to Students of Anthropology and Physical Education and Sports department for their help in collecting data to carry out the present work.

\section{References}

1. Peter AH (2010) Student-Designed Games: Strategies for Promoting Creativity, Cooperation, and Skill Development. Human Kinetics.

2. Norton K, Olds T (2001) Morphological evolution of athletes over the 20th century. Sports Medicine 31: 763-783.

3. Gualdi RE, Zaccagni L (2001) Somatotype, role and performance in elite volleyball players. J Sports Med Phys Fitness 41: 256-262.

4. Rienzi E, Drust B, Reilly T, Carter JE, Martin A (2000) Investigation of anthropometric and work rate profile of elite south American international soccer players. J Sport Med Phy Fit 40: 162-169.

5. Carter JEL (1984) Somatotype of Olympic athletes.

6. Morrow JR, Disch JC, Ward PE, Donavan TJ, Katch VL, et al. (1982) Anthropometric Strength and performance characteristics of American world class thrower. J Sport med Phy Fit 22: 73-79.

7. Guennadi G (1990) Anthropometric and physical fitness parameters for high jumpers of different are groups. Scientific journal 13: 9-10.

8. Bell W, Rhodes G (1975) The Morphological characteristics of the association football player. Brit. J Sports Med 9: 195-200.

9. Gomez A (2004) Athletes Targeting Healthy Exercise and Nutrition Alternatives. Archives of Pediatrics and Adolescent Medicine 158: 1084-1086.

10. Malhotra MS, Ramaswamy SS, Joseph NT, Sen Gupta J (1972) Functional capacity and body composition of Indian athletes. Indian J Physiol Pharmaco 16: 301-308.

11. Kansal DK, Gupta N, Gupta AK (1986) A study of in-transport differences in physique of Indian University football players.

12. Harrare D (1986) Principles of Sports Training

13. Durnin JVJA, Womerseley J (1974) The body fat assessed from total body density, estimation from skinfold thickness measurements on 481 men and women age from 16-72 years. Brit J Nutr 32: 77-97.

14. Dhayanithi R, Ravikumar P (2002) Continuous and Alternate Pace Endurance Methods and their Effects on Training and Determining on Selected Physical and Physiological variables among Boys. Research Bi-annual for movement 19: 16.

15. Parizkova J (1977) Body fat and physical fitness. The Hague, Nijhoff.

16. Burris B (2003) Measurement of Aerobic Capacity in College women Completed Research in Health, physical education and Recreation 15: 158. 